\title{
Platelet derived TGF- $\beta$ promotes cervical carcinoma cell growth by suppressing KLF6 expression
}

\author{
Ao-Di He ${ }^{1, *}$, Shao-Ping Wang ${ }^{2, *}$, Wen $\mathrm{Xie}^{1}$, Wei Song ${ }^{1}$, Shuo Miao ${ }^{1}$, Ru-Ping Yang ${ }^{1}$, \\ Ying Zhu ${ }^{1}$, Ji-Zhou Xiang ${ }^{1}$ and Zhang-Yin Ming ${ }^{1,3}$ \\ ${ }^{1}$ Department of Pharmacology, School of Basic Medicine, Tongji Medical College of Huazhong University of Science \& \\ Technology, Wuhan 430030, China \\ ${ }^{2}$ Department of Hepatobiliary Surgery, Affiliated Futian Hospital of Guangdong Medical College, Shenzhen 518033, China \\ ${ }^{3}$ The Key Laboratory for Drug Target Researches and Pharmacodynamic Evaluation of Hubei Province, Wuhan 430030, China \\ *These authors have contributed equally to this work and are designated as co-first authors
}

Correspondence to: Zhang-Yin Ming, email: zyming@hust.edu.cn

Keywords: platelet, platelet releasate, HeLa cervical carcinoma cells, Krüppel-like factor 6, transforming growth factor beta Abbreviations: CRP, collagen-related peptide; KLF6, Krüppel-like factor 6; MTT, 3-(4, 5-dimethylthiazol)-2, 5-diphenyltetrazolium bromide; siRNA, small interfering RNA; TGF- $\beta$, transforming growth factor beta

Received: April 25, $2017 \quad$ Accepted: July 12, $2017 \quad$ Published: August 03, 2017

Copyright: He et al. This is an open-access article distributed under the terms of the Creative Commons Attribution License 3.0 (CC BY 3.0), which permits unrestricted use, distribution, and reproduction in any medium, provided the original author and source are credited.

\section{ABSTRACT}

Platelets in the primary tumor microenvironment play crucial roles in regulating tumor growth, metastasis, and angiogenesis, but the underlying mechanisms are unclear. Here, we show that platelet releasates exhibited a proliferative effect on HeLa cells, and this effect correlated with a reduction of KLF6 expression. After incubation with either washed human platelets or collagen-related peptide (CRP) activated platelet releasates, expression of KLF6 in the HeLa cervical tumor cell line was markedly reduced. However, no significant difference was observed between control HeLa cells and HeLa cells incubated with resuspended activated platelet pellet. Moreover, the platelets' promoting effect on HeLa cell growth was significantly abolished in KLF6 silenced HeLa cells. In addition, blocking TGF- $\beta$ signaling with SB431542, a TGF- $\beta$ receptor inhibitor, also counteracted the effect of platelets on proliferation and KLF6 expression in HeLa cells. From these findings, we conclude that platelet derived TGF- $\beta$ promotes proliferation of HeLa cells by decreasing the expression of KLF6. The discovery that KLF6 is a key target of platelet-derived TGF- $\beta$ signaling in HeLa cells identifies a potential new therapeutic target for the prevention and treatment of cervical carcinoma.

\section{INTRODUCTION}

Cervical carcinoma is a worldwide disease and the second prevalent common cancer in women which constitutes a significant public health problem. $[1,2]$. Because of the sharply increasing incidence of cervical cancer [3], a detailed understanding of the molecular mechanisms associated with cervical carcinoma is needed to improve our approaches to treatment of this disease.

The relationship between platelets and cancer has been recognized for more than one hundred years, since the proposal of Trousseau syndrome in 1865 [4].
Extensive experimental evidences have been generated in support of an important role for circulating platelet in cancer progression, and researches revealed a role for physiologic platelet receptors and platelet granule contents in cancer growth, dissemination and angiogenesis [5-8]. Additionally, it has been reported that platelets accelerated the metastasis of cervical carcinoma by GPIIb/IIIa and $\alpha_{\mathrm{v}} \beta 3$ integrins [9]. However, the effects of platelet on cervical cancer cell proliferation and the molecular mechanisms underlying these associations have not been fully explored.

Transforming growth factor beta (TGF- $\beta$ ) controls the proliferation and differentiation of many types of 
non-malignant cells and is necessary for tumor cell extravasation and metastasis formation [10]. Platelets are a major source of TGF- $\beta[11]$. It has been reported that TGF- $\beta 1$ secreted from platelets promotes the proliferation of ovarian cancer cells [12], indicating a potential role for TGF- $\beta$ in platelet and cancer cell interactions. Although previous studies showed that HeLa cells treated with

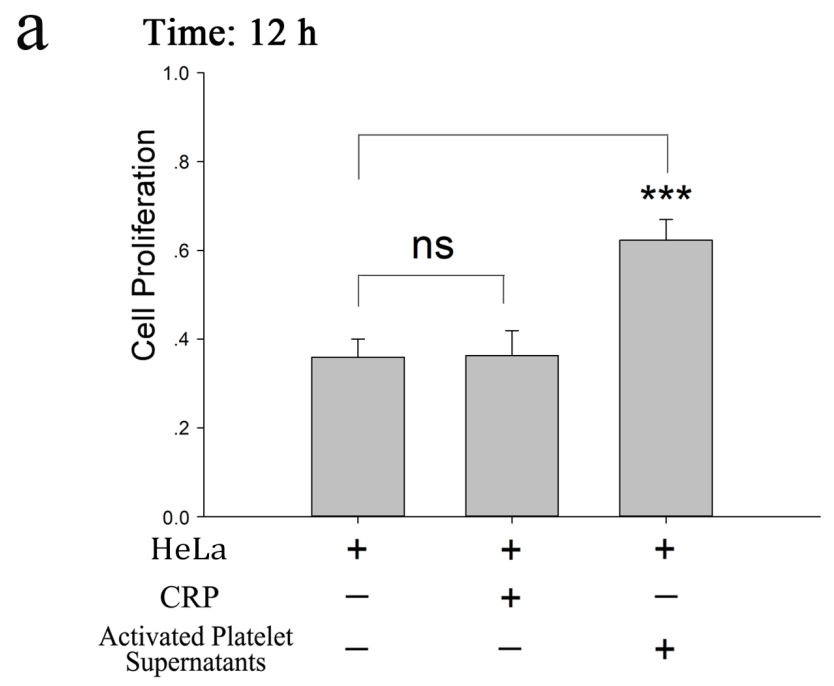

TGF- $\beta 1$ for 24 hour resulted in an increasing growth [13], whether platelet-derived TGF- $\beta$ involved in platelet- Hela cell interaction is still unknown.

Krüppel-like factor 6 (KLF6) is a ubiquitously expressed zinc finger transcription factor and has been characterized as a tumor suppressor gene that mediates growth suppression in a variety of human cancers [14-

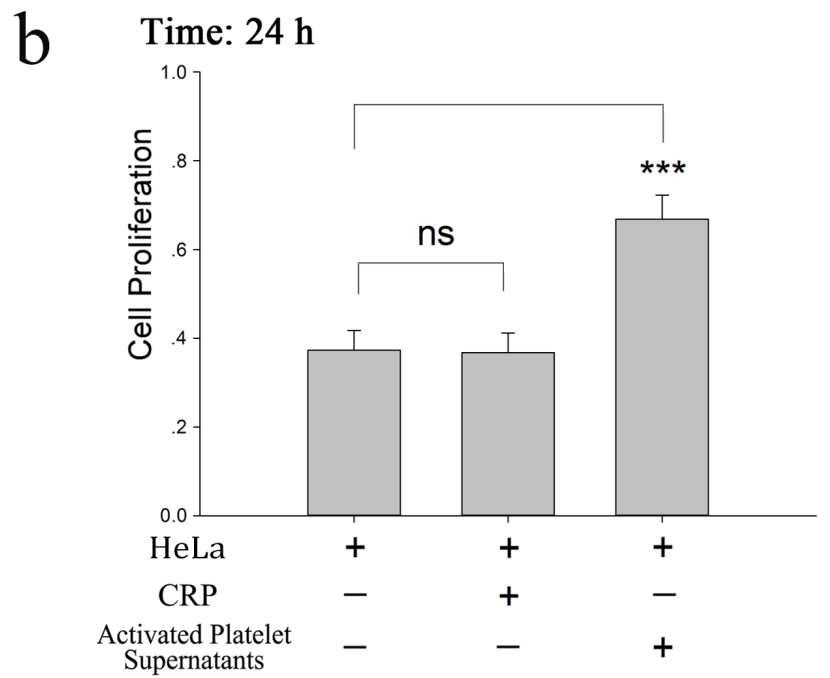

Figure 1: Proliferative effect of platelet releasates on HeLa cells. (a-b) Washed platelets $\left(2 \times 10^{8} / \mathrm{ml}\right)$ were treated with CRP $(0.8$ $\mu \mathrm{g} / \mathrm{ml})$. When platelets were fully activated, supernatants were isolated by centrifugation at $1000 \times \mathrm{g}$ for 10 min and then incubated with HeLa cells. MTT assays were performed to determine the proliferation effects of releasates from activated platelets on HeLa cells at 12 hour (a) or 24 hour (b). HeLa cells cultured in fresh medium were compared as a control. The results are expressed as the mean \pm SEM $\left({ }^{* * *} \mathrm{p}<0.001\right.$ compared with control). Five duplicate wells were set up for each group, and the experiment was repeated ten times.

a Time: $12 \mathrm{~h}$

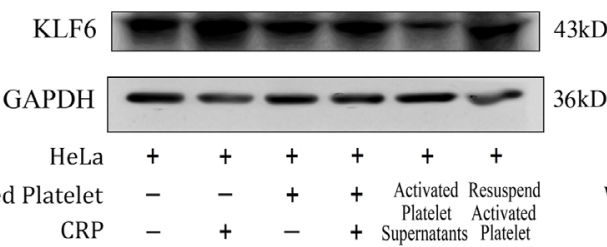

C

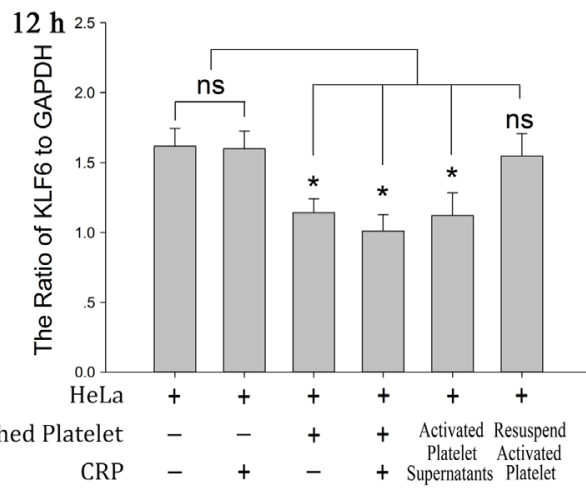

b Time: $24 \mathrm{~h}$

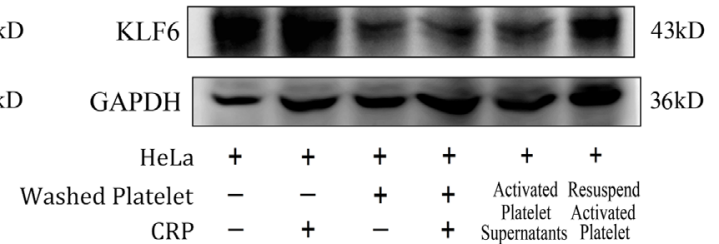

$\mathrm{d}$

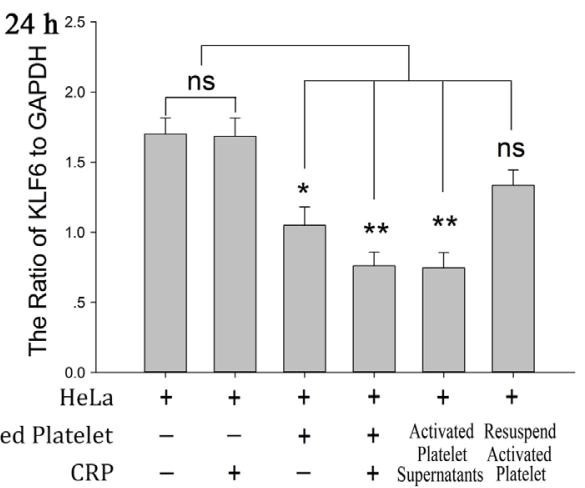

Figure 2: Effect of platelets on HeLa cells via reduced KLF6 expression. (a-b) HeLa cells were incubated with resting platelets, platelets treated withspecific stimulator CRP $(0.8 \mu \mathrm{g} / \mathrm{ml})$, washed platelets, washed platelets plus CRP, releasates of CRP-activated platelets, and the resuspended CRP-activated platelets pellet. KLF6 expression was measured by Western blot analysis in HeLa cells after a 12-hour (a) or 24-hour (b) treatment. (c-d) Quantitative analysis of the ratio of KLF6 levels to GAPDH is shown; data are presented as the mean \pm $\operatorname{SEM}\left(\mathrm{n}=8,{ }^{*} \mathrm{p}<0.05\right.$ and ${ }^{* *} \mathrm{p}<0.01$ compared with control). 
16]. Research has shown that TGF- $\beta$ can enhance the cooperation between KLF6 and $\mathrm{Sp} 1$ to regulate target genes in cells including HeLa cell [17]. Therefore, we hypothesized that the pro-proliferative effects of platelets on tumor cells are attributed to the ability of platelet-derived TGF- $\beta$ to decrease the expression of KLF6 in tumor cells.

a

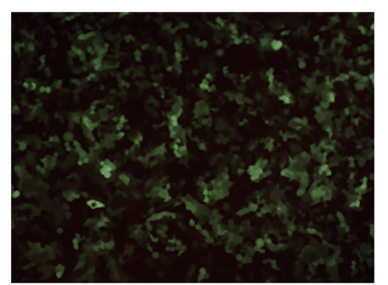

HeLa + Ctl siRNA

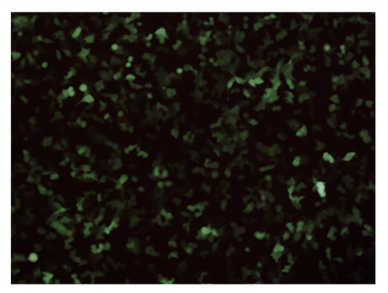

HeLa + KLF6 siRNA-2

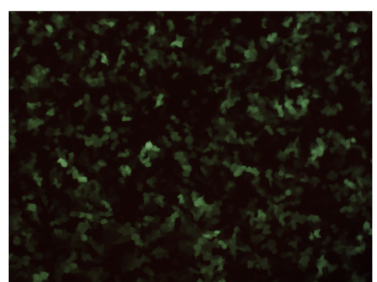

HeLa + KLF6 siRNA-1

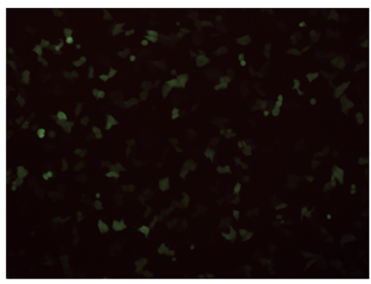

HeLa + KLF6 siRNA-3

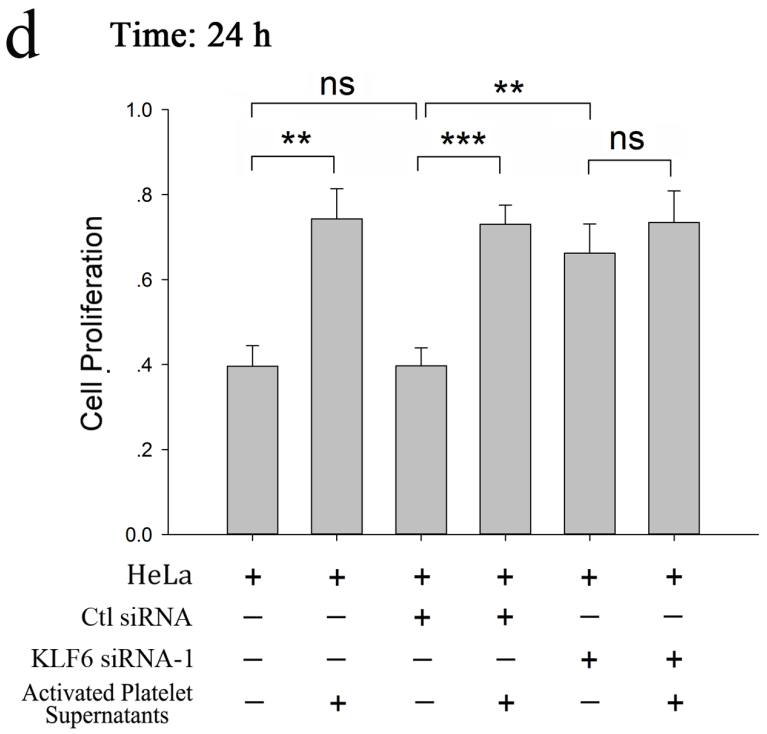

In the present study, we found that platelets or platelet granule contents, which are released upon platelet activation, reduced the expression of KLF6 and promoted growth in HeLa cells. Knockdown of KLF6 expression with siRNA substantially attenuated the pro-proliferative effect of platelets. Additionally, blocking TGF- $\beta$ signaling

b

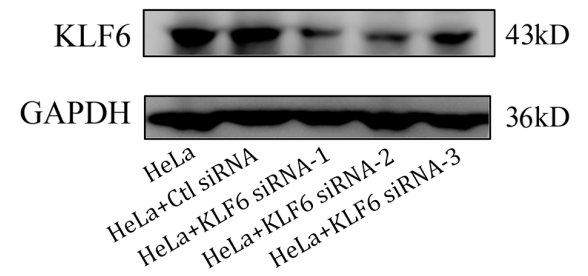

C

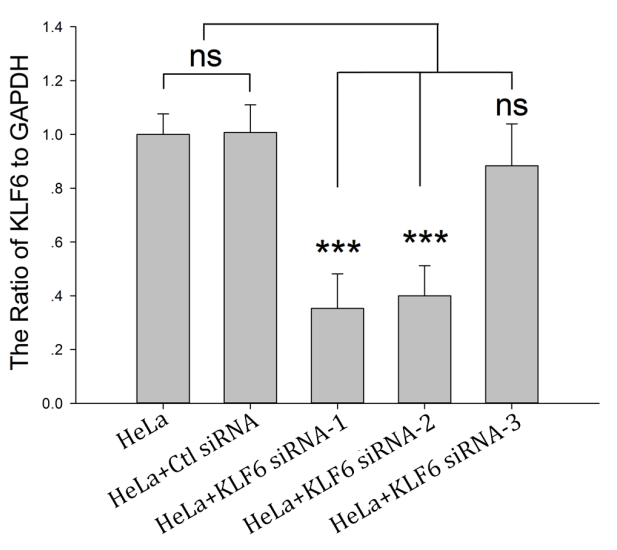

e Time: $24 \mathrm{~h}$

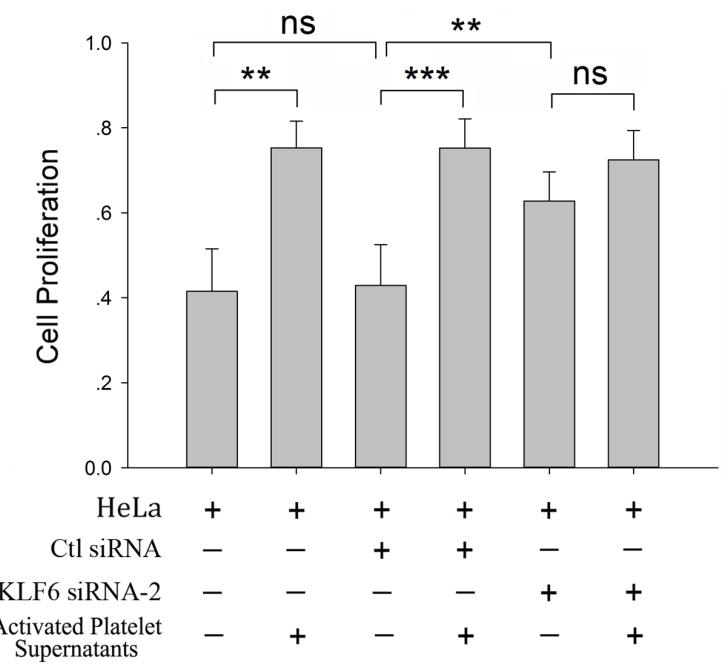

Figure 3: KLF6 gene silence dampened the proliferative effect of platelets on HeLa cells. (a-c) HeLa cells grown on 6-well plates were transfected with either control siRNA (Ctl siRNA) or 3 different KLF6 siRNAs (KLF6 siRNA-1, KLF6 siRNA-2 and KLF6 siRNA-3) for 48 hour. The expression of green fluorescence protein (GFP) was measured by a fluorescence microscope with 100X magnification (a). Four days after transfection, KLF6 expression was visualized by Western blot analysis (b). GAPDH was used as a loading control. (c) The ratio of KLF6 level to GAPDH summarized as a bar graph, data are presented as the mean \pm SEM $\left(n=4,{ }^{* * *}\right.$ p $<0.001$ compared with control). (d-e) Normal HeLa cells, HeLa cells transfected with control vector, KLF6 siRNA-1 (d) or KLF6 siRNA-2 (e) were incubated with CRP $(0.8 \mu \mathrm{g} / \mathrm{ml})$-activated platelet releasates. The MTT assay was performed to determine cell proliferation after a 24-hour incubation, and cells cultured in fresh medium were compared as control. Data are presented as the mean $\pm \mathrm{SEM}\left({ }^{* *} \mathrm{p}<0.01\right.$, ${ }^{* * *} \mathrm{p}<0.001$ compared with controls). Five duplicate wells were set up for each group, and the experiment was repeated six times. 
with a TGF- $\beta$ receptor inhibitor abrogated the stimulatory effect of platelets on HeLa cells. Taken together, these findings suggest that platelet releasates, especially TGF- $\beta$, promote the proliferation of HeLa cells by decreasing expression of KLF6.

\section{RESULTS}

\section{Platelets promote the growth of HeLa cells via reduced KLF6 expression}

In this study, we investigated the influence of platelets on HeLa cell proliferation. As shown in Figure 1a and $1 \mathrm{~b}, \mathrm{CRP}(0.8 \mu \mathrm{g} / \mathrm{ml})$-activated platelet supernatants accelerated the proliferation of HeLa cells in the MTT assay at 12 and 24 hour. In accordance with this promoting effect, KLF6, a tumor suppressor gene expressed in HeLa cells and deficient in platelets (Supplementary Figure 1), was proposed to play a potential role. In Figure $2 \mathrm{a}$ and $2 \mathrm{~b}$, after the incubation of HeLa cells with platelets treated with or without CRP for 12 and 24 hour, the expression of KLF6 in both groups was significantly suppressed compared with the HeLa control group. To define whether the platelet itself or its secretions were involved in this effect, the releasate in the supernatant was separated from the activated platelets by centrifugation. The supernatants also had a suppressive effect on KLF6 expression in HeLa cells. Conversely, the platelet itself, which was exhausted with platelet releasates and resuspended in fresh medium showed no significant influence on KLF6 expression (Figure 2a-2d).

\section{KLF6 gene silence dampened the proliferative effect of platelets on HeLa cells}

To confirm the critical role of KLF6 in the plateletmediated pro-proliferative effects on HeLa cells, HeLa cells were transfected with siRNA for KLF6 to knockdown its expression. As shown in Figure $3 a-3 c$, siRNA1 and siRNA2 decreased the expression of KLF6 in HeLa cells by $64.7 \%$ and $60.0 \%$, respectively. Neither siRNA3 nor scrambled siRNA significantly affected KLF6 expression, though the transfection efficiency for all four siRNAs was similar. Compared with scrambled siRNA-transfected HeLa cells, both siRNA1- and siRNA2- transfected HeLa cells had an improved growth rate, correlating with the reduced level of KLF6 expression (Figure 3d and 3e). Though platelet releasates were able to promote the growth of HeLa cells transfected with scrambled RNA, they had no effect on the proliferation of HeLa cells in which KLF6 was silenced by either siRNA1 or siRNA2 $(66.27 \%$ vs $73.46 \%$ and $62.77 \%$ vs $72.47 \%$, respectively; $\mathrm{p}>0.05$ ) (Figure $3 \mathrm{~d}$ and $3 \mathrm{e}$ ).
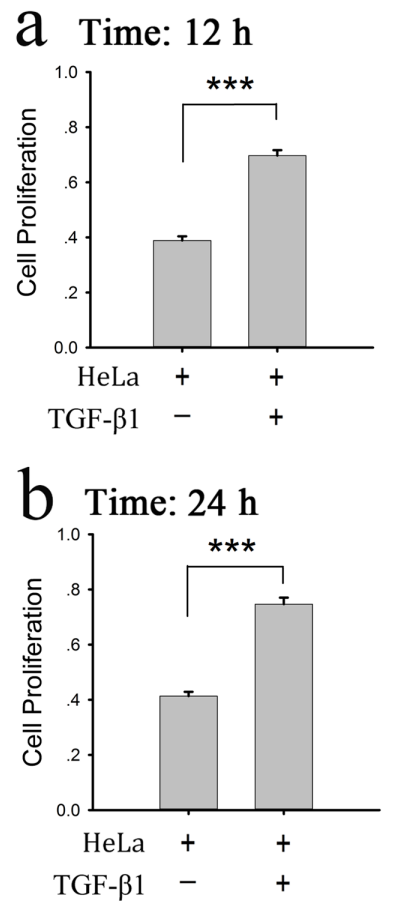

C Time: $12 \mathrm{~h}$

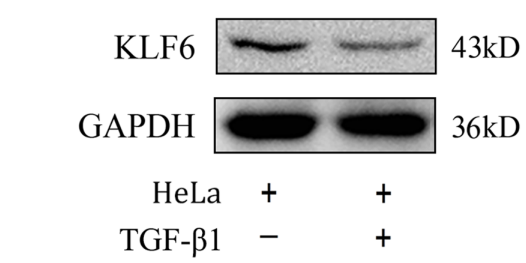

e $12 \mathrm{~h}$

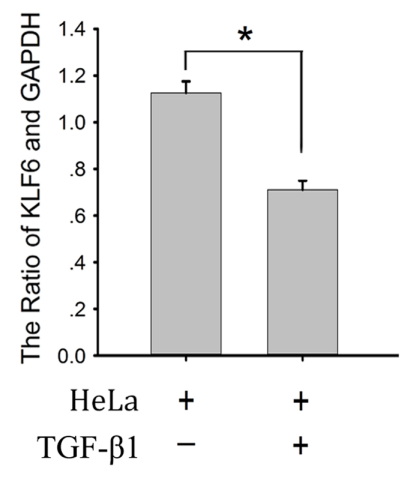

d Time: $24 \mathrm{~h}$

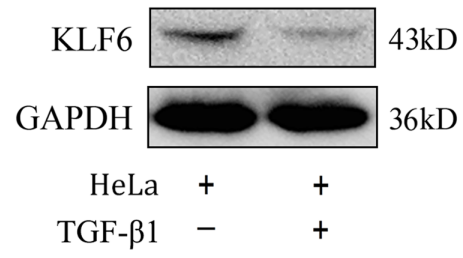

f $24 \mathrm{~h}$

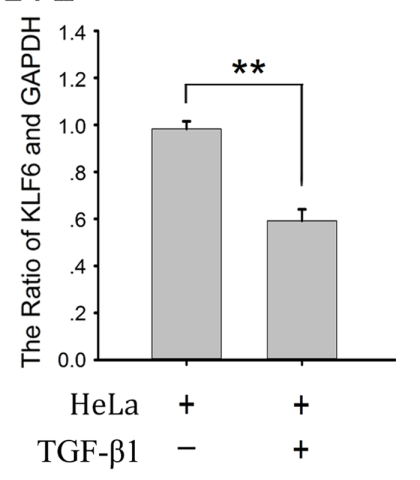

Figure 4: Recombinant TGF- $\beta 1$ increased proliferation and decreased KLF6 expression of HeLa cells. (a-b) HeLa cells were treated with human recombinant TGF- $\beta 1(10 \mathrm{ng} / \mathrm{ml})$ for 12 (a) or 24 (b) hours, the proliferation of cells was assessed by MTT assay. Cells cultured in fresh medium were compared as a control. The results are expressed as the mean \pm SEM $\left({ }^{* * *} \mathrm{p}<0.001\right.$ compared with control). Five duplicate wells were set up for each group, and the experiment was repeated 3 times. (c-f) HeLa cells were treated with TGF- $\beta 1(10 \mathrm{ng} / \mathrm{ml})$ for 12 (c) or 24 (d) hours, expression of KLF6 was measured by a western blot analysis. Cells cultured in fresh medium were used as a control. A quantitative analysis of the ratio of KLF6 to GAPDH expression is shown (e-f), and data are presented as the mean $\pm \operatorname{SEM}\left(\mathrm{n}=3,{ }^{*} \mathrm{p}<0.05,{ }^{* *} \mathrm{p}<0.01\right.$ compared with control). 
a

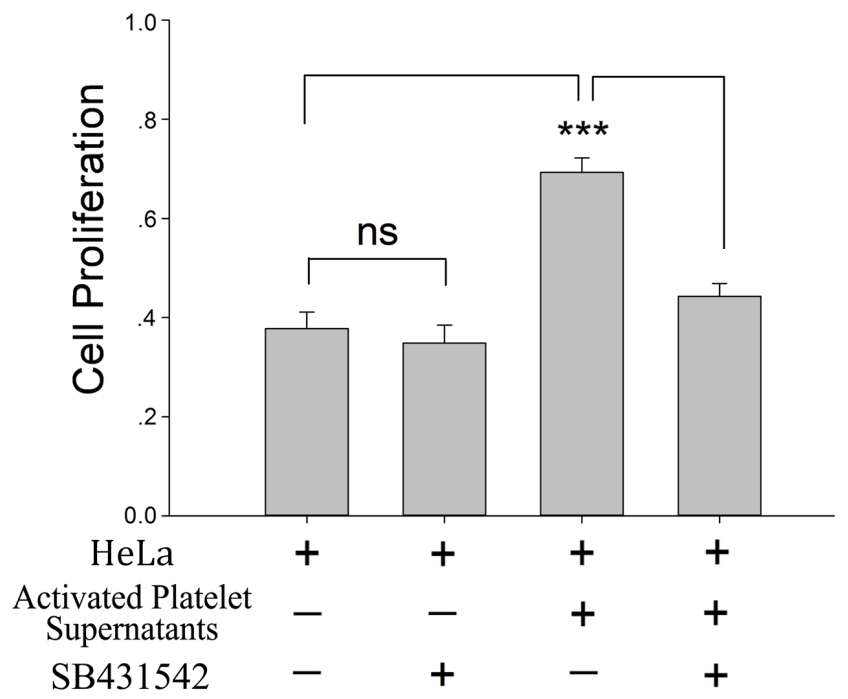

b

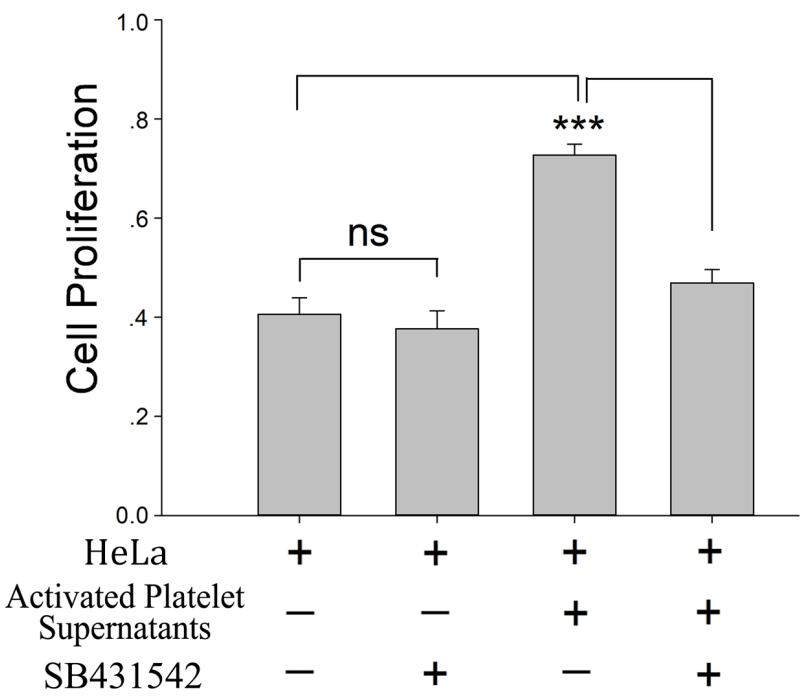

Figure 5: Platelet derived TGF- $\beta$ promotes HeLa cell proliferation. (a-b) Supernatants from CRP $(0.8 \mu \mathrm{g} / \mathrm{ml})$-activated platelets $\left(2 \times 10^{8} / \mathrm{ml}\right)$ were isolated by centrifugation at $1000 \times \mathrm{g}$ for $10 \mathrm{~min}$. HeLa cells were treated with the platelet supernatants in the absence and presence of the TGF- $\beta$ receptor inhibitor SB431542 $(10 \mu \mathrm{M})$. The MTT assay was used to determine the proliferation effects of the releasates from activated platelets on HeLa cells at 12 hour (a) or 24 hour (b). HeLa cells cultured in fresh medium were used as control. Each experiment was repeated 10 times in triplicate. Data are presented as the mean $\pm \operatorname{SEM}\left(\mathrm{n}=10,{ }^{* * *} \mathrm{p}<0.001\right.$ compared with controls $)$.

a Time: $12 \mathrm{~h}$
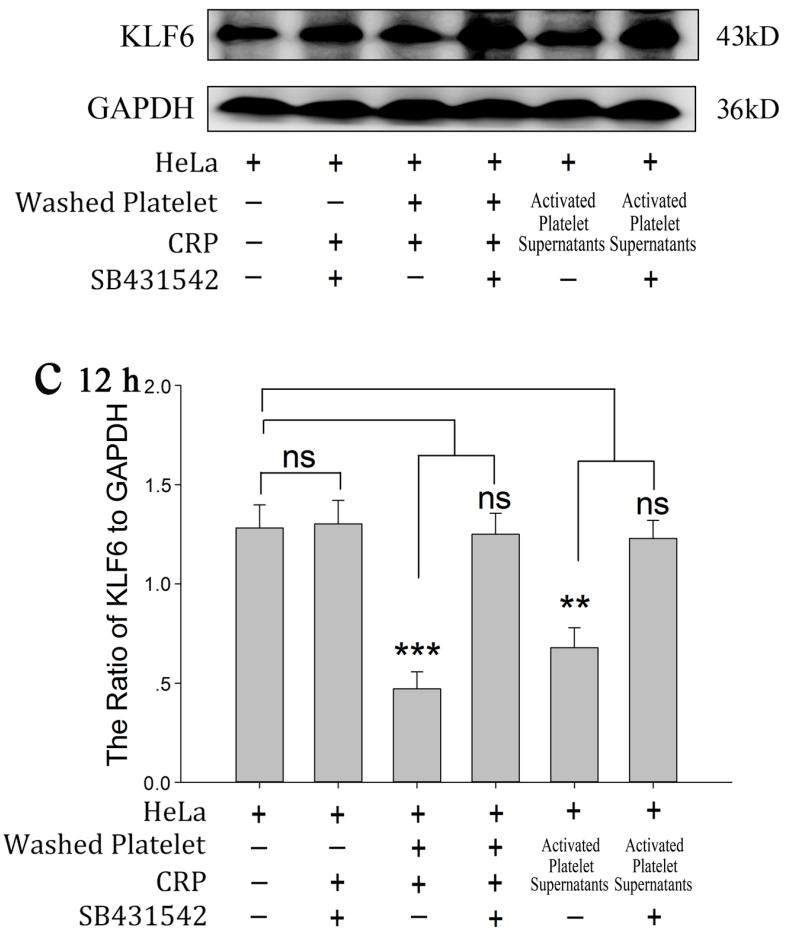

b Time: $24 \mathrm{~h}$
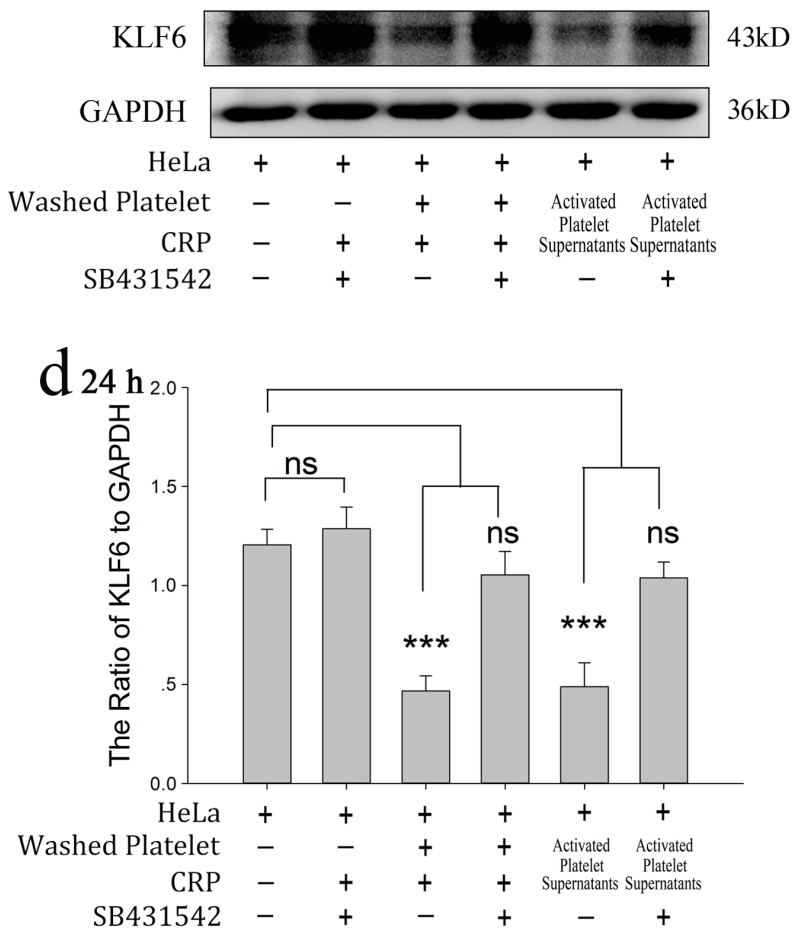

Figure 6: Platelet-derived TGF- $\beta$ regulates the expression of KLF6 in cervical carcinoma cells. (a-b) HeLa cells were incubated with the TGF- $\beta$ receptor inhibitor SB431542 $(10 \mu \mathrm{M})$, platelets treated with CRP $(0.8 \mu \mathrm{g} / \mathrm{ml})$, washed platelet plus CRP, and supernatants of CRP-activated platelets in the absence and presence of SB431542 $(10 \mu \mathrm{M})$. KLF6 expression was detected by Western blot analysis in HeLa cells after 12 hour (a) or 24 hour (b) of treatment. (c-d) Quantification of data are presented as the mean $\pm \operatorname{SEM}(\mathrm{n}=5$, ${ }^{* *} \mathrm{p}<0.01,{ }^{* * * *} \mathrm{p}<0.001$ compared with controls). 


\section{Platelet-derived TGF- $\beta$ promotes the proliferation of tumor cells}

Above study showed platelet granule contents promote HeLa cell growth and attenuate KLF6 expression of HeLa cells. Platelets are an important source of bioavailable TGF- $\beta$ for tumor cells [18]. Reduced expression of TGF- $\beta 1$ receptors was found along with a decreased proliferation of ovarian cancer cells when they were exposed to platelets [12]. Therefore we proposed that platelet-derived TGF- $\beta$ was involved in tumor growth and affected KLF6 expression. We firstly detected whether human recombinant TGF- $\beta 1$ could affect proliferation and KLF6 expression of HeLa cells. Figure 4 showed that TGF- $\beta 1$ could markedly increase HeLa cell growth (Figure $4 \mathrm{a}$ and $4 \mathrm{~b}$ ) and reduce expression of KLF6 in HeLa cells (Figure $4 \mathrm{c}-4 \mathrm{f}$ ) at the 12 and 24 hour time points.

To demonstrate the role of platelet-derived TGF- $\beta$ in HeLa cell growth, SB431542, a TGF- $\beta$ receptor blocker, was incubated with HeLa cells before treated with platelet or its releasate. The promoting effect of platelet secretion on the proliferation of HeLa cells was reversed by SB431542 (Figure 5a and 5b). Both CRP $(0.8$ $\mu \mathrm{g} / \mathrm{ml}$ )-treated platelets and their releasate could reduce the expression of KLF6 at the 12 and 24 hour time points (Figure $6 \mathrm{a}$ and $6 \mathrm{~b}$ ), which promoted proliferation of HeLa cells. These effects could be blocked by the TGF- $\beta$ receptor inhibitor $(10 \mu \mathrm{M})$ (Figure 6a-6d).

\section{DISCUSSION}

It has been well recognized that platelet and its releasates are key players in the regulation of tumor angiogenesis and metastasis [19]. In support of this concept, we found that the inclusion of washed human platelets in culture media significantly promoted HeLa cell proliferation. Surprisingly, we found that the expression of KLF6 was reduced by incubating HeLa cells with platelets. A TGF- $\beta$ receptor antagonist reversed the effects on HeLa cell proliferation and KLF6 expression.

KLF6 is a ubiquitously expressed tumor suppressor gene. In cervical carcinoma, loss and/or mutation of KLF6 results in its inactivation and/or downregulation, contributing to cervical cancer pathogenesis via the effects on targeted genes that control cell proliferation and differentiation $[20,21]$. In our experiments, HeLa cells incubated with platelet releasates exhibited lower levels of expression of KLF6 and enhanced proliferation relative to HeLa cells cultured in the absence of platelet pellet. This observed effect of platelets on KLF6 expression was independent of direct cross contact between platelet and tumor cells because the pellet of CRP-activated platelets, which had secreted all of its granules components, had no effect on the expression of KLF6 in HeLa cells. In addition, the proliferation of HeLa cells in which KLF6 was silenced showed no significant difference in the presence of platelet releasate. These data demonstrate that the pro-proliferative effect of platelet releasates on $\mathrm{HeLa}$ cells is due to the downregulation of KLF6 expression in HeLa cells by factors released from platelets and is independent of platelet-tumor cell direct interaction.

TGF- $\beta$ has been reported to be involved in the regulation of KFL6 expression in different cells [17, 22], and recombinant TGF- $\beta 1$ could increase cell proliferation and reduce KLF6 expression in HeLa cell line. Moreover, recent studies showed that platelet-derived TGF- $\beta$ is known to be involved in the EMT and metastasis of tumor cells via the TGF- $\beta /$ Smad and NF-kB pathways [23]. We therefore hypothesized that platelet-derived TGF- $\beta$ is responsible for the effects of platelet releasates on KLF6 expression and HeLa cell proliferation. Consistent with our hypothesis, blocking TGF- $\beta$ signaling with a TGF- $\beta$ receptor inhibitor abolished the platelet releasate-induced downregulation of KLF6 expression and the proliferation of HeLa cells.

Collectively, these data reveal a pivotal role for KLF6 in the contribution of platelets and their releasates such as TGF- $\beta$ to the proliferation of HeLa cells. These findings broaden our knowledge about the role of platelets in tumor progression, which may offer a novel treatment strategy in cervical carcinoma.

\section{MATERIALS AND METHODS}

\section{Tumor cell lines and transfection}

HeLa cells were obtained from the Chinese Center for Type Culture Collection (CCTCC). Cells were routinely cultured in Dulbecco's modified Eagles' medium (DMEM, HyClone Logan, UK) supplemented with $10 \%$ newborn calf serum (Gibco, Grand Island, NY, USA) and antibiotics (penicillin, streptomycin $100 \mathrm{~g} /$ $\mathrm{mL}$, Amresco, OH, USA) and incubated in a humidified incubator containing $5 \% \mathrm{CO}_{2}$, at $37^{\circ} \mathrm{C}$. siRNA against KLF6 and control non-targeting siRNA were obtained from Genechem (Shanghai, China). Cells were seeded overnight in six-well plates at a density of $5 \times 10^{5}$ cells per well. Cells were transfected with the siRNA targeting KLF6 or the control siRNA using polybrene $(10 \mu \mathrm{g} / \mathrm{ml}$, Sigma-Aldrich, St. Louis, MO, USA), according to the manufacturer's instructions. Transfection efficiency was determined by green fluorescent protein (GFP) expression using fluorescence microscopy. When the GFP expression was greater than $70 \%$ in each group after transfection, Western blot analysis was performed to determine which siRNA sequence sufficiently suppressed KLF6 expression.

\section{Treatment of tumor cells with washed human platelets}

Human blood was collected from healthy volunteers. Washed platelets were prepared as described previously 
[24] and resuspended in fresh medium. When incubated with HeLa cells, platelets were activated by collagenrelated peptide (CRP, $0.8 \mu \mathrm{g} / \mathrm{ml}$ ), which was obtained as a gift from the Blood Research Institute at the Blood Center of Wisconsin. Platelet releasates were collected following centrifugation of CRP-stimulated platelets at $1000 \times \mathrm{g}$ for $10 \mathrm{~min}$.

Before being incubated with platelets or platelet releasates, HeLa cells were seeded in six-well plates and incubated at $37^{\circ} \mathrm{C}$ in a humidified incubator containing $5 \% \mathrm{CO}_{2}$. When $\mathrm{HeLa}$ cells reached approximately $80 \%$ confluence, washed human platelets $\left(2 \times 10^{8} / \mathrm{ml}\right)$, platelet releasates or platelet pellets were added. In some experiments, HeLa cells were treated with human recombinant TGF- $\beta 1$ (10 ng/ml, Sigma-Aldrich, St. Louis, MO, US) or TGF- $\beta 1$ receptor inhibitor, SB431542 (10 $\mu \mathrm{M}$, Selleckchem, Houston, TX, USA), before incubation with human platelets.

All experimental procedures were approved by the Ethics Committee for the Use of Human Subjects of Huazhong University of Science and Technology. These studies were conducted in accordance with the Declaration of Helsinki.

\section{Western blot}

After treatment, cells were washed with PBS. Lysis of cells was performed on ice by scraping in lysis buffer supplemented with $2 \%$ protease inhibitors (Calbiochem, MA, USA). Proteins present in cell lysates were separated by SDS-PAGE and transferred to PVDF membranes (EMD Millipore Corporation, Billerica, MA, USA). The membranes were incubated with a primary mouse antibody against KLF6 (1:250, Santa Cruz Biotechnology, CA, USA). A horseradish peroxidase-conjugated anti-mouse antibody was used as a secondary antibody, and signals were detected by enhanced chemiluminescence (Thermo Scientific, USA). GAPDH (1:5,000, Cell Signaling Technology, MA, USA) was used as a protein loading control.

\section{MTT assay}

The effect of platelets on cell proliferation was determined with a colorimetric 3-(4, 5-dimethylthiazol)-2, 5-diphenyltetrazolium bromide (MTT) (Amresco, OH, USA) assay. HeLa cells were plated at an initial density of 4000 cells per well into 96-well plates and incubated at $37^{\circ} \mathrm{C}$ overnight. The cells were then incubated with platelet releasates. Negative controls were treated with medium only. The absorbance (OD) was measured with a microplate reader (Tecan Sunrise, Grodig, Austria) at a $490 \mathrm{~nm}$ wavelength.

\section{Statistical analysis}

Data throughout the manuscript are presented as the mean \pm SEM. Comparisons were made using Student's t-test, with $p<0.05$ considered statistically significant.

\section{Author contributions}

He AD and Wang SP performed the research, analyzed the data, and wrote the manuscript;

Xie W, Song W, Miao S, Yang RP and Zhu Y performed the experiments;

Xiang JZ helped design the research;

Ming ZY designed the experiments, analyzed the data, and wrote the manuscript.

\section{CONFLICTS OF INTEREST}

All authors have no conflicts of interest to declare.

\section{FUNDING}

This study was supported by the National Natural Science Foundation of China (81273574 and 81473270 to ZY Ming).

\section{REFERENCES}

1. Waggoner SE. Cervical cancer. Lancet. 2003; 361: 2217-25. https://doi.org/10.1016/s0140-6736(03)13778-6.

2. Ferlay J, Shin HR, Bray F, Forman D, Mathers C, Parkin DM. Estimates of worldwide burden of cancer in 2008: GLOBOCAN 2008. Int J Cancer. 2010; 127: 2893-917. https://doi.org/10.1002/ijc.25516.

3. Peralta-Zaragoza O, Bermudez-Morales VH, PerezPlasencia C, Salazar-Leon J, Gomez-Ceron C, MadridMarina V. Targeted treatments for cervical cancer: a review. Onco Targets Ther. 2012; 5: 315-28. https://doi.org/10.2147/ OTT.S25123.

4. Varki A. Trousseau's syndrome: multiple definitions and multiple mechanisms. Blood. 2007; 110: 1723-9. https:// doi.org/10.1182/blood-2006-10-053736.

5. Jain S, Harris J, Ware J. Platelets: linking hemostasis and cancer. Arterioscler Thromb Vasc Biol. 2010; 30: 2362-7. https://doi.org/10.1161/ATVBAHA.110.207514.

6. Gay LJ, Felding-Habermann B. Platelets alter tumor cell attributes to propel metastasis: programming in transit. Cancer Cell. 2011; 20: 553-4. https://doi.org/10.1016/j. ccr.2011.11.001.

7. Buergy D, Wenz F, Groden C, Brockmann MA. Tumorplatelet interaction in solid tumors. Int J Cancer. 2012; 130: 2747-60. https://doi.org/10.1002/ijc.27441.

8. Gay LJ, Felding-Habermann B. Contribution of platelets to tumour metastasis. Nat Rev Cancer. 2011; 11: 123-34. https://doi.org/10.1038/nrc3004.

9. Liu Y, Zhao F, Gu W, Yang H, Meng Q, Zhang Y, Yang H, Duan Q. The roles of platelet GPIIb/IIIa and alphavbeta3 integrins during HeLa cells adhesion, migration, and invasion to monolayer endothelium under static and dynamic shear flow. J Biomed Biotechnol. 2009; 2009: 829243. https://doi.org/10.1155/2009/829243. 
10. Ikushima H, Miyazono K. TGFbeta signalling: a complex web in cancer progression. Nat Rev Cancer. 2010; 10: 41524. https://doi.org/10.1038/nrc2853.

11. Assoian RK, Komoriya A, Meyers CA, Miller DM, Sporn MB. Transforming growth factor-beta in human platelets. Identification of a major storage site, purification, and characterization. J Biol Chem. 1983; 258: 7155-60.

12. Cho MS, Bottsford-Miller J, Vasquez HG, Stone R, Zand B, Kroll MH, Sood AK, Afshar-Kharghan V. Platelets increase the proliferation of ovarian cancer cells. Blood. 2012; 120: 4869-72. https://doi.org/10.1182/blood-2012-06-438598.

13. Maliekal TT, Anto RJ, Karunagaran D. Differential activation of Smads in HeLa and SiHa cells that differ in their response to transforming growth factor-beta. J Biol Chem. 2004; 279: 36287-92. https://doi.org/10.1074/jbc. M404568200.

14. Narla G, Heath KE, Reeves HL, Li D, Giono LE, Kimmelman AC, Glucksman MJ, Narla J, Eng FJ, Chan AM, Ferrari AC, Martignetti JA, Friedman SL. KLF6, a candidate tumor suppressor gene mutated in prostate cancer. Science. 2001; 294: 2563-6. https://doi.org/10.1126/ science. 1066326.

15. Kremer-Tal S, Reeves HL, Narla G, Thung SN, Schwartz M, Difeo A, Katz A, Bruix J, Bioulac-Sage P, Martignetti JA, Friedman SL. Frequent inactivation of the tumor suppressor Kruppel-like factor 6 (KLF6) in hepatocellular carcinoma. Hepatology. 2004; 40: 1047-52. https://doi. org/10.1002/hep.20460.

16. Andreoli V, Gehrau RC, Bocco JL. Biology of Kruppellike factor 6 transcriptional regulator in cell life and death. IUBMB Life. 2010; 62: 896-905. https://doi.org/10.1002/ iub.396.

17. Botella LM, Sanz-Rodriguez F, Komi Y, Fernandez LA, Varela E, Garrido-Martin EM, Narla G, Friedman SL, Kojima S. TGF-beta regulates the expression of transcription factor KLF6 and its splice variants and promotes co-operative transactivation of common target genes through a Smad3-Sp1-KLF6 interaction. Biochem J. 2009; 419: 485-95. https://doi.org/10.1042/BJ20081434.

18. Takemoto A, Okitaka M, Takagi S, Takami M, Sato S, Nishio M, Okumura S, Fujita N. A critical role of platelet TGF-beta release in podoplanin-mediated tumour invasion and metastasis. Sci Rep. 2017; 7: 42186. https://doi. org/10.1038/srep42186.

19. Joyce JA, Pollard JW. Microenvironmental regulation of metastasis. Nat Rev Cancer. 2009; 9: 239-52. https://doi. org/10.1038/nrc2618.

20. Lee UE, Ghiassi-Nejad Z, Paris AJ, Yea S, Narla G, Walsh M, Friedman SL. Tumor suppressor activity of KLF6 mediated by downregulation of the PTTG1 oncogene. FEBS Lett. 2010; 584: 1006-10. https://doi.org/10.1016/j. febslet.2010.01.049.

21. Kremer-Tal S, Narla G, Chen Y, Hod E, DiFeo A, Yea S, Lee JS, Schwartz M, Thung SN, Fiel IM, Banck M, Zimran E, Thorgeirsson SS, et al. Downregulation of KLF6 is an early event in hepatocarcinogenesis, and stimulates proliferation while reducing differentiation. J Hepatol. 2007; 46: 645-54. https://doi.org/10.1016/j.jhep.2006.10.012.

22. Dionyssiou MG, Salma J, Bevzyuk M, Wales S, Zakharyan L, McDermott JC. Krüppel-like factor 6 (KLF6) promotes cell proliferation in skeletal myoblasts in response to TGF $\beta$ / Smad3 signaling. Skelet Muscle. 2013; 3: 7.

23. Labelle M, Begum S, Hynes RO. Direct signaling between platelets and cancer cells induces an epithelialmesenchymal-like transition and promotes metastasis. Cancer Cell. 2011; 20: 576-90. https://doi.org/10.1016/j. ccr.2011.09.009.

24. Liu G, Xie W, He AD, Da XW, Liang ML, Yao GQ, Xiang JZ, Gao CJ, Ming ZY. Antiplatelet activity of chrysin via inhibiting platelet alphaIIbbeta3-mediated signaling pathway. Mol Nutr Food Res. 2016; 60: 1984-93. https:// doi.org/10.1002/mnfr.201500801. 